\title{
PEMINDAIAN PENERAPAN BIMBINGAN DAN KONSELING DENGAN PENDEKATAN MULTIKULTURAL DI SMA
}

\author{
Helmuth Y Bunu \\ Fakultas Keguruan dan Ilmu Pendidikan Universitas Palangkaraya \\ email: hyb047@yahoo.co.id
}

\begin{abstract}
Abstrak: Tujuan penelitian kualitatif ini adalah untuk memindai penerapan bimbingan dan konseling dengan pendekatan multikultural di SMA. Penelitian menggunakan pendekatan kualitatif. Informan penelitian adalah guru BK, Kepala sekolah, para guru, siswa, pengurus OSIS, dan komite sekolah SMA Negeri 1 Palangkaraya. Data dikumpulkan dengan menggunakan pengamatan partisipatif, wawancara mendalam, dan dokumentasi. Data dianalisis dengan menggunakan empat tahap penelitian kualitatif dari Miles dan Hubermann, yaitu pengumpulan data, reduksi data, klasifikasi data, dan penarikan simpulan. Berdasarkan hasil penelitian, secara umum dapat disimpulkan sebagai berikut. (1) Tujuan layanan konseling dengan pendekatan multikultural adalah memberikan bantuan kepada siswa multikultur untuk mengatasi masalah yang dihadapi dengan baik. (2) Jenis layanan konseling antara lain membantu klien mengembangkan perilaku santun, membantu mengatasi kecemasan, menggali dan potensi siswa. (3) Karakteristik khusus yang diterapkan adalah dengan memberikan layanan konseling individual. (4) Layanan konseling dengan pendekatan multikultural telah memanfaatkan secara maksimal berbagai media konseling yang ada.
\end{abstract}

\section{Kata kunci: bimbingan konseling, multikultural, pemindaian, layanan}

\section{THE IMPLEMENTATION OF MULTICULTURAL APPROACH IN GUIDANCE AND COUNSELING IN HIGH SCHOOLS}

\begin{abstract}
The objective of this qualitative study is to scan the implementation of guidance and counseling through multicultural approachin senior high school. The informants of this study werethe counseling teacher, principal, teachers, students, student organization (OSIS), and school committee of SMA Negeri 1 Palangkaraya. Data were collected through participatory observation, interview, and documentation. Data were analyzed using four qualitative research phases of Miles and Hubermann, namely data collection, data reduction, data classification, and conclusions drawing. Based on the research results, in general it can be concluded that: (1) the purpose of multicultural approach of counseling services is to provide good assistance to multicultural students to overcome their problems; (2) the counseling services are provided to help students in developing polite behavior, overcoming anxiety, and exploring talent; (3) personal counseling services are also provided; (4) the multicultural counselingservices have utilized the available counseling media.
\end{abstract}

Keywords: counseling, multicultural, scanning, service

\section{PENDAHULUAN}

Sebagaimana diketaui bersama, setiap sekolah rata-rata diikuti oleh siswa dari multietnis, multibudaya, dan multiagama. Jarang sekali terjadi ada sekolah umum, tetapi siswanya hanya berasal dari satu etnis, satu agama, dan satu budaya. Apalagi saat ini, dengan semakin tingginya frekwensi mobilitas orang, semakin besar pula peluang terjadinya pembauran etnis, agama, dan budaya.
Melihat fenomena itu, setiap guru BK dalam melaksanakan proses konseling di sekolah sudah dapat dipastikan akan berhadapan dengan siswa dari multi etnis, agama, dan budaya. Oleh kerena itu, sudah pada tempatnya, apabila sekolah dalam memberikan pelayanan pendidikan termasuk pelayanan bimbingan dan konseling (BK) selalu memperhatikan keragaman ini.

Permasalahan yang ada saat ini dapat diidentifikasi sebagai berikut. Pertama, kompetensi guru BK yang ada di setiap sekolah belum mampu 
secara spesifik memberikan layanan konseling dengan menggunakan pendekatan multikultur. Hal ini terjadi karena pembekalan kepada mahasiswa BK di kampus belum secara spesifik menerapkan pendekatan multikultur.

Kedua, sekolah belum mampu secara maksimal menyiapkan soft ware, hard ware, braind ware layanan konseling yang benar-benar menggunakan pendekatan multikultur. Dengan kata lain, sekolah belum menetapkan tujuan layanan, jenis-jenis layanan, karakteristik layanan, berbagai media layanan, dan bahan evaluasi untuk meningkatkan pelayanan konseling multikultur secara prima.

Ketiga, pemberian layanan konseling pada jenjang pendidikan menengah yang selama ini diterapkan lebih menekankan bimbingan bersosialisasi, berinteraksi, berkarier, dan berkomunikasi antarsiswa. Pemberian seluruh layanan konseling tersebut belum secara khusus menekankan pendekatan multikultur.

Ketiga realitas permasalahan inti tersebut, apabila dihadapkan pada harapan layanan konseling yang dicita-citakan, masih terdapat stereotif atau jurang pemisah yang cukup lebar. Melalui penelitian ini diharapkan, jurang menganga tersebut dapat dihimpitkan mendekati cita-cita pelayanan konseling prima dengan pendekatan multikultur.

Berbagai realitas yang diharapkan dalam pemberian layanan konseling di sekolah hendaknya merupakan layanan sosial yang bersifat humanis yang bertujuan membantu siswa yang multikultur dalam mengatasi masalah di sekolah pada khususnya dan masalah di dalam keluarga/ masyarakat pada umumnya.

Layanan bimbingan dan konseling di sekolah dengan siswa multikultur mempunyai spesifikasi tersendiri. Faktor yang membedakan adalah: a) konselor harus benar-benar memperhatikan perbedaan individu dari berbagai budaya; b) konselor tidak boleh memukul rata dalam memberikan masukan terhadap siswa, meskipun permasalahannya sama; c) konselor harus mengikuti budaya yang dianut siswa, bukan siswa yang harus mengikuti budaya konselor, dan d) konselor harus belajar berbagai budaya yang dianut oleh siswa baik melalui internet, tokoh adat, tokoh masyarakat, siswa yang benar-benar memahami adat istiadat, dan sumber belajar lainnya (Siskandar, 2013:21).
Bimbingan (guidance) multikultur diartikan sebagai upaya menunjukkan jalan (showing the way); memimpin (leading); menuntun (conducting); memberikan petunjuk (giving instruction); mengatur (regulating); mengarahkan (governing); dan memberikan nasihat (giving advice) kepada siswa dari multikurtur.

Bimbingan multikultur juga dapat dimaknai sebagai upaya: a) memberikan informasi, yaitu menyajikan pengetahuan yang dapat digunakan siswa dari multi kultur untuk mengambil suatu keputusan atau memberitahukan sesuatu sambil memberikan nasihat; b) memberikan arahan kepada siswa dari multi kultur; c) memberikan nasihat kepada siswa dari multi kultur untuk melakukan atau tidak melakukan tindakan yang berkaitan dengan proses penyelesaikan pendidikan; d) mengarahkan, menuntut ke suatu tujuan, yaitu cita-cita yang dimiliki oleh siswa; e) memberikan bimbingan, pelajaran dan pedoman kepada siswa dari multi kultur; dan f) memberikan arahan kepada siswa dari multi kultur bagaimana menanggulangi proses penyelesaian problematika hidup (Busro, 2015:45).

Bimbingan multikultur merupakan bantuan kepada anak-anak dari seluruh kalangan suku, agama, ras, dan budaya dalam pertumbuhan dan perkembangan mereka menjadi pribadi-pribadi yang sehat. Bimbingan multikultur merupakan usaha membantu siswa dari multikultur tanpa melihat etnis, suku, agama, ras, dan budayanya khusunya untuk mereka yang memerlukan dalam mencapai apa yang menjadi idaman kehidupannya (Busro, 2015:54).

Sementara itu, counseling multikultur dapat diartikan sebagai: a) nasihat (to obtain counsel) bagi siswa dari multikultur untuk berbuat baik kepada dirinya dan orang lain; b) anjuran (to give counsel) bagi siswa dari multikultur untuk melakukan sesuatu demi keberhasilan pendidikan; dan c) pembicaraan (to take counsel) tentang hal yang baik dan buruk yang diberikan kepada siswa dari multikultur berkaitan dengan proses belajar mengajar di sekolah, di kalangan keluarga di rumah dan di masyarakat luas (Supangat, 2014:45).

Dengan adanya nasihat, anjuran, pembicaraan hal-hal yang baik, diharapkan siswa dari multikultur pun akan terlepas dari berbagai permasalahan yang bisa menghambat keberhasilan mereka dalam menggapai cita-cita yang telah digantung di alam pikiran dan perasaan mereka. 
Dengan demikian, konseling dalam konteks multikultur merupakan pemberian nasehat, pemberian anjuran dan pemberian masukan antara konselor dan konseli dalam satu permasalahan yang dihadapi konseli tanpa memandang suku, agama, ras, budaya, umur, jenis kelamin agar dapat memecahkan masalah yang sedang dihadapi (Siskandar, 2013:36).

Konselor yang bekerja di sekolah dengan siswa dari multikultur berusaha membantu klien dengan metode yang sesuai atau cocok dengan kebutuhan klien tersebut dalam hubungannya dengan keseluruhan program, agar supaya individu dapat mempelajari lebih baik tentang dirinya untuk memperoleh tujuan hidup yang lebih realistis, sehingga klien dapat menjadi anggota masyarakat yang berbahagia dan lebih produktif (Sukardi, 2014:13).

Dilihat dari pengertian yang demikian itu, hendaknya sekolah dengan siswa dari multikultur di dalam melaksanakan program bimbingan dan konseling, menugaskan konselor yang mampu bekerja secara profesional dengan memperhatikan secara cermat keragaman siswanya.

Akhirnya, konseling di sekolah dengan siswa dari multikultur juga menangani kesulitankesulitan dalam bidang pendidikan atau pengajaran yang meliputi kelemahan dalam keterampilan, kebiasaan belajar, perencanaan kurukulum, dan masalah-masalah emosional (Sukardi, 2014:16).

\section{Metode}

Penelitian menggunakan pendekatan kualitatif yang dikembangkan oleh Miles dan Huberman. Metode kualitatif dipilih, karena fenomena yang hendak diteliti, proses pengambilan data, dan analisis yang paling tepat untuk mendeskripkan pelaksanaan layanan bimbingan dan konseling multikultur di SMA Negeri1 Palangkaraya adalah penelitian kualitatif. Dengan dasar reasoning di atas, maka pelaksanaan layanan bimbingan dan konseling multikultur dapat digali secara jernih, mendalam, tuntas hingga akar permasalahannya.

Penelitian dilakukan di SMA Negeri 1 Palangkaraya. Informan penelitian ini yaitu, guru BK, kepala sekolah, para guru non-BK, siswa, pengurus OSIS, dan komite sekolah. Penelitian dilaksanakan pada bulan Januari s.d. Maret 2016.

Data dikumpulkan dengan menggunakan metode pengamatan partisipatif, wawancara mendalam, dan dokumentasi. Untuk meningkat- kan dan mempertangungjawabkan validitas data dilakukan triangulasi data, mulai dari cek, recek, dan croscek data, serta memperlama waktu penelitian hingga mendapatkan data yang bersifat jenuh. Data dianalisis dengan menggunakan empat langkah, yang dikembangkan oleh Miles dan Huberman (2000) yaitu pengumpulan data, reduksi data, klasifikasi data, dan penarikan simpulan.

\section{HASIL DAN PEMBAHASAN \\ Hasil \\ Tujuan Layanan Konseling Multikultur}

Tujuan layanan konseling multikultur di SMA N 1 Palangkaraya tidak terlepas dari visi dan misi layanan konseling di sekolah tersebut. Visi pelayanan bimbingan dan konseling sebagai sekolah yang multikultur adalah terwujudnya kehidupan kemanusiaan yang membahagiakan melalui tersedianya pelayanan bantuan dalam pemberian dukungan perkembangan dan pengentasan masalah agar peserta didik dari berbagai etnis, budaya, dan agama dapat berkembang secara optimal, mandiri, dan bahagia.

Makna dari visi BK pada sekolah multikultur tersebut adalah bahwa: 1) kehidupan kemanusiaan tidak selamanya bahagia, oleh karena itu melalui bimbingan dan konseling multikultur bisa mendapatkan kebahagiaan; 2) kebahagiaan itu dapat dicapai antara lain melalui tersedianya pelayanan bantuan dalam bentuk bimbingan dan konseling multikultur yang terintegrasi dalam proses pembelajaran di sekolah; dan 3) pemberian dukungan perkembangan dan pengentasan masalah bertujuan agar peserta didik dari multikultur dapat berkembang secara optimal, mandiri dan bahagia baik dalam arti lahir maupun batin.

Adapun misi bimbingan dan konseling yang canangkan di sekolah tersebut adalah sebagai berikut. Pertama, misi pendidikan, yaitu memfasilitasi pengembangan peserta didik dari multikultur melalui pembentukan perilaku efektifnormatif dalam kehidupan keseharian dan masa depan. Artinya, dengan bimbingan dan konseling di sekolah, konselor berupaya memfasilitasi pengembangan peserta didik yang berasal dari multi etnis, budaya, dan agama melalui pembentukan perilaku efektif sesuai dengan norma-norma yang berlaku dalam kehidupan keseharian dan masa depan.

Kedua, misi pengembangan, yaitu memfasilitasi pengembangan potensi dan kompetensi peserta didik dari multi etnis, budaya, dan aga- 
ma dalam lingkungan sekolah, keluarga, dan masyarakat. Artinya, 1) bimbingan dan konseling di sekolah berupaya untuk memfasilitasi pengembangan potensi peserta didik dari multikultur di dalam lingkungan sekolah, keluarga dan masyarakat, 2) bimbingan konseling multikultur berupaya meningkatkan kompetensi peserta didik dari multikultur di dalam lingkungan sekolah, keluarga dan masyarakat.

Ketiga, misi pengentasan masalah, yaitu memfasilitasi pengentasan masalah peserta didik dari multikultur dengan mengacu pada kehidupan efektif sehari-hari. Artinya, bimbingan dan konseling di sekolah dengan siswa dari multikultur berupaya memfasilitasi pengentasan masalah peserta didik, dan bimbingan dan konseling di sekolah yang siswanya multikultur berupaya membantu siswa mengatasi problematika pembelajaran mengacu pada kehidupan efektif sehari-hari.

Secara umum, tujuan konseling yang diberikan adalah membantu individu dari multikultur dalam mewujudkan dirinya menjadi manusia seutuhnya agar mencapai kebahagiaan hidup.

Secara khusus, tujuan konseling yang diberikan adalah sebagai berikut. (1) Membantu individu dari multikultur agar tidak mengahadapi masalah. 2) Membantu individu dari multikultur mengatasi masalah yang sedang dihadapinya. 3 ) Membantu individu dari multikultur memelihara dan mengembangkan situasi dan kondisi yang baik atau yang telah baik agar tetap baik atau menjadi lebih baik, sehingga tidak akan menjadi sumber masalah bagi dirinya dan orang lain. 4) Membantu individu dari multikultur mencegah timbulnya problem-problem yang berkaitan dengan kehidupan bermasyarakat. 5) Membantu individu dari multikultur memahami dan menghayati tatacara hidup bermasyarakat. 6) Membantu individu dari multikultur mau dan mampu hidup bermasyarakat. 7) Membantu individu mencegah timbulnya problem yang berkaitan dengan kehidupan bermasyarakatnya, antara lain dengan jalan memahami problem yang dihadapinya individu dari multikultur dan memahami kondisi dan lingkugnan sosialnya individu dari multikultur, 8) membantu memahami dan menghayati berbagai cara untuk mengatasi problem kehidupan bermasyarakat dari multikultur. 9) Membantun menetapkan pilihan upaya pencegahan problem yang dihadapi masyarakat dari multikultur. 10) Membantu individu memelihara situasi dan kondisi kehidupan bermasyarakat agar tetap baik dan mengembalikannya agar jauh lebih baik, yakni dengan cara memelihara situasi dan kondisi kehidupan bermasyarakatnya yang semula menghadapi problem dan telah teratasi agar tidak menimbulkan atau menjadi masalah kembali, dan mengembangkan situasi dan kondisi kehidupan bermasyarakatnya yang telah menjadi baik itu agar bertambah baik.

\section{Jenis-Jenis Layanan Konseling Multikultur}

Secara umum, jenis layanan konsleing multikultur dapat dibagi atas tiga jenis.

Pertama, Berdasarkan banyaknya orang yang dibimbing pada waktu dan tempat tertentu: (1) Bilamana siswa dari multikultur yang dilayani hanya satu orang, maka digunakan istilah bimbingan individual atau bimbingan perseorangan. (2) Bilamana siswa dari multikultur yang dilayani lebih dari satu orang, maka digunakan istilah bimbingan kelompok. (3) Bimbingan langsung berarti pelayanan bimbingan yang diberikan kepada siswa dari multikultur oleh tenaga bimbingan sendiri, dalam suatu pertemuan tatap muka dengan satu siswa atau sejumlah siswa. (4) Bimbingan tidak langsung. Bimbingan ini dapat dimaknai sebagai: (a) bentuk pelayanan bimbingan yang diberikan oleh tenaga bimbingan melalui tenaga pendidik yang lain; (b) pelayanan yang diberikan oleh tenaga bimbingan melalui suatu medium, misalnya dalam brosur, pamflet, tulisan dalam majalah sekolah, tulisan pada papan bimbingan dan lain sebagainya.

Kedua, Berdasarkan tujuan yang ingin dicapai dalam memberikan pelayanan bimbingan kepada siswa dari multikultur, meliputi: (1) mendampingi siswa dari multikultur dalam perkembangan yang sedang berjalan, supaya berlangsung seoptimal mungkin; (2) membantu siswa dari multikultur dalam mengoreksi atau membetulkan proses perkembangan yang telah mengalami salah jalur, supaya kemudian berlangsung dengan lebih baik; (3) membekali siswa dari multikultur, supaya lebih siap menghadapi tantangan-tantangan di masa akan datang.

Ketiga, Berdasarkan bidang tertentu dalam kehidupan siswa dari multikultur, atau aspek perkembangan tertentu pada siswa.

Secara lebih rinci, jenis-jenis pelayanan konseling bagi siswa dari multikultur, yang diterapkan antara lain meliputi: (1) bimbingan pemecahan, yaitu bimbingan pemecahan masalah yang dihadapi siswa dari multikultur; (2) bimbing- 
an preventif, yaitu bimbingan untuk upaya pencegahan agar si anak dari multikultur tidak mengalami masalah; (3) bimbingan developmental, yaitu bimbingan untuk mengembangkan potensi, bakat, dan minat siswa dari multikultur; (4) bimbingan korektif, yaitu bimbingan untuk mengobati atau mengatasi berbagai masalah yang dihadapi siswa dari multikultur; (5) bimbingan penyembuhan, yaitu bimbingan untuk menyembuhkan siswa dari multikultur yang secara psikologis mengalami masalah sehingga perlu disembuhkan; (6) bimbingan pemeliharaan, yaitu bimbingan yang berupaya untuk memelihara kondisi kesehatan psikologis siswa dari multikultur pasca-mengalami berbagai permasalahan yang bisa menghambat proses keberhasilan pendidikan; (7) bimbingan belajar, yaitu bimbingan kepada siswa dari multikultur yang mengalami kesulitan belajar, dengan harapan dapat dengan mudah menerima berbagai materi pelajaran di kelas; (8) bimbingan perseorangan, yaitu bimbingan yang diberikan kepada perseorangan dari multikultur dengn kasus yang khusus sehingga memerlukan metode yang khusus pula; (9) bimbingan kelompok, yaitu bimbingan yang diberikan kepada kelompok dari multikultur dengan permasalahan yang sama, sama-sama mengalami kesulitan belajar matematika, bahasa Inggris, atau lainnya; (10) bimbingan akademi, yaitu bimbingan yang diberikan kepada siswa dari multikultur berkaitan dengan proses pembelajaran, atau bimbingan untuk melanjutkan ke pendidikan yang lebih tinggi; dan lain-lain.

\section{Karakteristik Konseling Multikultur}

Karakteristik konseling dapat dideskripsikan sebagai berikut. (1) Konseling berusaha mempengaruhi perubahan sebagian besar dari tingkah laku klien dari multikultur secara sukarela. (2) Konseling berupaya menyajikan kondisi yang dapat memperlancar dan mempermudah perubahan sukarela siswa dari multikultur. (3) Klien atau konseli mempunyai batas gerak sesuai dengan tujuan konseling yang secara khusus ditetapkan bersama oleh konselor dan klien dari multikultur pada waktu permulaan proses konseling itu. (4) Kondisi yang memperlancar perubahan tingkah laku itu di selenggarakan melalui wawancara (tidak semua wawancara adalah konseling, tetapi konseling selalu menyangkut wawancara dengan konseli dari multikultur). (5) Suasana mendengarkan terjadi dalam konseling, tetapi tidak semua proses konseling itu terdiri dari mendengarkan itu saja.
(6) Konselor memahami klien dari multikultur. (7) Konseling diselenggarkan dalam keadaan pribadi multikultur dan hasilnya dirahasiakan. (8) Klien dari multikultur mempunyai masalah-masalah psikologis dan konselor memiliki keterampilan atau keahlian di dalam membantu memecahkan masalah-masalah psikologis yang dihadapi klien dari multikultur.

Di dalam komunikasi antarpribadi, karakteristik khusus yang dibentuk dan dibina selama wawancara konseling berlangsung seluruhnya dilaksanakan dengan menggunakan urutan lima fase: (1) pembukaan yang di dalamnya mulai dibentuk hubungan antarpribadi antara konselor dan konseli dari multikultur; (2) introduksi masalah yang ingin dibicarakan oleh konseli dengan konselor; (3) pendalaman dan penggalian masalah sehingga inti masalah serta latar belakangnya menjadi lebih jelas bagi konseli dan konselor; (4) pembahasan cara mengatasi masalah dengan memilih di antara beberapa alternatif yang tersedia atau dengan meninjau sikap dan pandangan yang lebih sesuai; dan (5) penutup yang di dalamnya keseluruhan proses konseling diringkas dan penyelesaian atas masalah ditegaskan kembali serta hubungan antarpribadi diakhiri.

Teknik khusus serta keterampilan komunikasi antarpribadi yang khas diterapkan oleh konselor untuk konseling dibentuk dan dibina sehingga memuaskan untuk kedua belah pihak. (1) Beberapa contoh teknik verbal yang diterapkan oleh konselor di sekolah ini ialah, pujaan, sanjungan, ucapan terima kasih yang tulus, refleksi perasaan, klarifikasi pikiran dan dukungan. (2) Beberapa contoh teknik yang nonverbal yang digunakan di sekolah ini ialah anggukan, acungan jempol, senyuman tulus, mimik wajah yang happy dan humanis, jabat tangan yang erat, gerak tangan dan lengan, gerakan tungkai, isyarat mata, pengaturan jarak antara tempat-tempat duduk dan.

Konselor harus menggali kepada siswa dari multikultur mengenai beberapa hal, yaitu: (1) situasinya kebatinan yang saat ini dirasakan oleh siswa dari multikultur; (2) kebutuhan yang dirasakan siswa dari multikultur; (3) kemampuan siswa dari multikultur dalam mengusahakan perubahan dalam mengatur atau mengontrol kehidupannya sendiri; dan (4) kesediaan siswa dari multikultur untuk melibatkan diri dalam mengusahakan suatu perubahan.

Misalnya, seorang siswa dari etnis tertentu menghubungi konselor sekolah dengan maksud 
dan tujuan menemukan berbagai cara supaya keluarganya jangan campur tangan dalam hal memilih program studi lanjutan, atau ingin mendapatkan strategi agar orang tua tidak mengarahkan jenis mata pencaharian yang menjadi cita-cita,

Karakteristik khusus lainnya juga terlihat pada pola penanganan siswa bermasalah. Pembinaan siswa dari multikultur dilaksanakan oleh seluruh unsur pendidikan di sekolah, seperti: guru BK, guru agama, guru kewarganegaraan/ pancasila, wali kelas, seluruh guru mata pelajaran, pembina pramuka, komite sekolah, dan orang tua.

Pola tindakan terhadap siswa dari multikultur yang secara tidak sengaja bermasalah di sekolah adalah sebagai berikut. (1) Seorang siswa tanpa melihat etnis, agama, suku, budaya yang melanggar tata tertib dapat ditindak oleh kepala sekolah, guru, atau wali kelas. (2) Selanjutnya wali kelas merekomendasikan kepada guru BK untuk menanganinya. (3) Guru BK berperan untuk mengetahui sebab-sebab yang melatarbelakangi sikap dan tindakan siswa tersebut. (4) Guru BK bertugas membantu menangani masalah siswa tersebut dengan meneliti latar belakang tindakan siswa melalui serangkaian wawancara dan informasi dari sejumlah sumber data. (5) Guru BK membantu mencarikan solusi yang dikomunikasikan kepada wali kelas agar tidak terjadi lagi pelanggaran yang sama.

Ada beberapa hal lain yang secara khusus selalu diperhatikan oleh guru BK saat menangani masalah siswa dari multikultur antara lain: (1) memperhatikan budaya yang melatarbelakangi selama siswa hidup dalam lingkungan keluarga dan masyarakat; (2) menggali latar belakang budaya siswa dengan cara menanyakan latar belakang orang tua, bahasa sehari-hari yang digunakan di rumah dan di masyarakat; (3) menghindarkan berbagai perkataan, tindakan, dan perbuatan yang bertentangan dengan budaya yang dianut siswa; (4) menggunakan pendekatan budaya yang paling disukai siswa; (5) memastikan bahwa siswa menyukai pendekatan yang digunakan oleh guru selama memberikan bantuan kepadanya; (6) mengurangi keterlibatan orang tua, karena ada budaya orang tua yang akan selalu membela anak dan akan merasa sangat tersinggung bila anaknya disalahkan atau ada orang lain yang memberi nasihat kepada anaknya.

\section{Media Konseling Multikultur}

Media BK merupakan seluruh media yang dapat membantu guru BK dalam melaksanakan tugas sehari-hari baik mendia tidak bergerak maupun bergerak, baik media manual maupun elektronik, baik media berbasis benda riil maupun berbasis IT, baik media sederhana maupun canggih.

Seluruh media BK tersebut telah dimiliki oleh guru. Dalam proses pengadaan media, ada beberapa upaya guru yaitu: membuat sendiri, meminta bantuan siswa, meminta bantuan ahli menulis dan menggambar, menggunakan sarana komputer, menggunakan jasa konsultan, bekerja sama dalam kelompok kerja guru, mencari di intenet dengan menyebutkan sumbernya, meminta ijin untuk meniru dan memodifikasi dari berbagai media yang telah dimiliki oleh sekolah yag sudah maju, studi banding ke sekolah dan perguruan tinggi yang sudah memberikan pelayanan BK secara modern, bermain ke toko-toko media pendidikan yang menyediakan media BK secara lengkap, belajar dari guru-guru senior, mengikuti berbagai workshop, seminar, lokakarya, simposium, diskusi yang membahas media BK, Studi banding ke luar negeri, membaca berbagai buku berbobot baik dari dalam maupun dari luar negeri.

Prinsip yang digunakan untuk memperoleh media tersebut dilakukan dengan cara: merintis sedikit demi sedikit, pelan-pelan/tidak terburu-buru, cermat dan teliti, dari yang paling mudah-hingga yang paling sulit, dari yang paling sederhana hingga paling canggih, dari yang tidak bergerak menjadi bergerak/hidup, dari media yang hanya meniru hingga yang inovatif-kreatif, dari yang murah hingga yang paling mahal, dan dari buatan sendiri hingga membeli.

Seluruh media tersebut sangat bermanfaat dalam melakukan layanan dan komunikasi. Komunikasi antarpribadi yang bersifat multikultur dalam konseling merupakan hal yang tidak dapat dihindari, manakala menghendaki tatap muka secara langsung, rahasia, bersifat pribadi, dan dapat memahami perasaan kedua belah pihak.

Komunikasi konseling dua arah dengan siswa dari multikultur tidak hanya dilakukan secara langsung tetapi juga dapat secara tidak langsug melalui berbagai media baik cetak maupun elektronik. Sistem infomasi yang digunakan di SMA N 1 Palangkaraya dengan siswa multikultur dalam bimbingan konseling variasinya sangat 
banyak, mulai dari bimbingan konseling on-line, penggunaan sistem bimbingan konseling yang modern, block bimbingan konseling, face book konseling, blackbarry massanger (BBM), SMS bimbingan konseling, aplikasi line, twitter, email, whatsapp, hangouts, dan berbagai aplikasi media sosial lainnya.

Sebagaimana diketahui sistem komunikasi jaringan dan internet dengan siswa multikultur semakin mempermudah para guru, termasuk guru BK untuk berkomunikasi dengan banyak siswa dari multikultur secara simultan, dan mengelola tugas-tugas jarak jauh dan kerja tim. Layanan konseling multikultur dapat dipisahkan dari lokasi dan diatur dari jarak jauh. Internet dan teknologi jaringan yang dikembangkan mampu meningkatkan presisi (ketepatan) dan fleksibilitas dari sekolah multikultur dan fungsi out put dalam skala kecil maupun besar.

Penggunaan IT dengan siswa dari multikultur menjadikan segala proses kegiatan menjadi lebih segalanya, antara lain lebih mudah, lebih murah, lebih cepat, lebih akurat, lebih ringan, lebih kreatif, lebih inovatif, lebih mempunyai jangkauan yang lebih luas, lebih memberikan kepastian dalam segala hal, lebih mampu memberikan keyakinan, dan berbagai kelebihan lainnya. Pemanfaatan IT dengan siswa dari multikultur digunakan pendekatan humanis yang mengedepankan aspek kemanusiaan. Dengan demikian, konseli akan merasa: diorangkan, dihormati, disayangi, diapresiasi, diperhatikan, dan didengarkan.

Dengan kata lain, dalam perspektif humanis dengan siswa dari multikultur, seorang konselor meskipun telah menggunakan teknologi IT yang canggih, tetap melakuan tindakan yang sesuai dengan etika profesi konselor antara lain: memanusiakan, menolong, mendengarkan, membantu, mecarikan jalan keluar, memahami, menghayati, mengobati, mencegah, dan sebagainya.

Meskipun dengan siswa dari multikultur sudah menggunakan sistem informasi yang canggih, selalu menanamkan budaya etika yang diimplementasikan yaitu: (1) adanya komitmen atau kesepakatan antara sekolah, dan seluruh pemangku kepentingan seperti orang tua wali murid, masyarakat sekitar sekolah, dinas pendidikan, pengawas sekolah, departemen pendidikan dalam hal berkomunikasi dengan pihak sekolah; (2) adanya pimpinan dan seluruh orang yang terlibat dalam dunia pendidikan memfasilitasi siswa dalam bentuk IT dan non-IT sehingga siswa memperoleh layanan pendidikan yang paling prima; dan (3) menyusun tata tertib atau peraturan tata krama berkomuniksi dengan IT yang disepakati bersama oleh komunitas sekolah.

Dalam penanaman budaya etika oleh konselor, ada tiga bentuk implementasi yang diperhatikan yaitu: (1) membentuk paham etika lembaga pendidian (educational institution credo); (2) menyusun program etika yang merancang aktivitas ganda untuk memfasilitasi pimpinan dan bawahan yang terlibat dalam lembaga pendidikan dalam memahami organisasi pendidikan tersebut; dan (3) membangun kode etik lembaga pendidikan tersendiri misalnya kode etik guru dan kode etik kepala sekolah.

\section{Pembahasan}

Tujuan konseling multikultur yang telah ditentukan antara lain membantu individu dari multikultur dalam mewujudkan dirinya menjadi manusia seutuhnya agar mencapai kebahagiaan hidup. Selain itu, tujuan konseling yang diberikan adalah membantu individu untuk mengatasi masalah, membantu individu mengembangkan situasi yang baik, membantu individu mencegah timbulnya problem, membantu individu memahami tatacara hidup bermasyarakat dan lain-lain.

Tujuan konseling multikultur yang telah ditentukan pada dasarnya sejalan dengan tujuan konseling yang dijelaskan oleh Hohenshill (2013:32) yang menyatakan bahwa terdapat lima tujuan dalam suatu proses konseling, yaitu: (1) perubahan perilaku atau pola kehidupan seharihari, baik di sekolah, di lingkungan bermain, di lingkungan keluarga, dan dimasyarakat; (2) perbaikan pola relasi sosial dengan orang lain dari berbagai etnis, buku, bahasa, agama, dan lain-lain; (3) peningkatan kemampuan menghadapi tantangan hidup secara efisien dan efektif sehingga tidak melakukan berbagai pemborosan baik waktu, tenaga maupun biaya; (4) belajar cara membuat keputusan tentang sesuatu yang penting; dan (5) kontinuitas pengembangan diri baik di bidang pendidikan, agama, bahasa, budaya, atau bidang keterampilan yang lain sesuai dengan kemampuan yang dimiliki.

Jenis konseling yang dilakukan sebagai proses membantu pribadi dengan menyediakan informasi yang merangsang klien untuk mengembangkan perilaku-perilaku yang memungkinkan berhubungan secara lebih efektif dengan ling- 
kungannya. Pemberian bantuan yang berkaitan dengan kecemasan atau konflik yang dirasakan oleh siswa dari multikultur dilakukan dengan sangat cermat, hati, hati, dan bersifat individual. Pemberian bantuan juga diberikan untuk mengatasi masalah-masalah pribadi, sosial, pendidikan dan vokasional yang dirasakan siswa dari lintas budaya.

Karakteristik khusus konseling yang diterapkan dilakukan dengan melibatkan siswa dari lintas etnis, budaya, dan agama mencakup semua bentuk hubungan antara konselor dan konseli. Suasana hubungan dalam konseling di sekolah dengan siswa dari lintas budaya meliputi penggunaan wawancara untuk mendapatkan dan memberikan berbagai informasi, meningkatkan kematangan, dan memberikan bantuan melalui pengambilan keputusan dan upaya terapi atau penyembuhan.

Hasil penelitian ini menguatkan hasil temuan Atamimi (2015:67) yang menemukan bahwa di dalam menerapkan bimbingan konseling di sekolah dasar diperlukan keterampilan psikologis yang mumpuni, karena selain siswa sekolah dasar tersebut multi etnis, juga sifat dan karakter anak yang satu dengan yang lain sangat berbeda.

Karakteristik khusus konseling yang juga diterapkan dilakukan dengan meningkatkan kesehatan mental konseli yang berasal dari lintas etnis, budaya, dan agama. Konseling yang dilakukan melibatkan hubungan antarpribadi, yaitu antara seorang konseli dengan satu atau lebih klien dengan menggunakan metode psikologis atas dasar pengetahuan sistematik tentang kepribadian manusia dalam upaya meningkatkan kesehatan mental klien.

Hasil penelitian ini juga sejalan dengan hasil penelitian Saliman dkk. (2014:34) yang menunjukkan bahwa di "sekolah pembauran" merupakan sekolah yang menggunakan Whole School Approach yang meliputi sangat menghargai dan menghormati perbedaan siswa baik dari sisi suku, ras, agama, budaya, maupun perbedaan lainnya. Seluruh pembauran itu tertian dalam visi dan kebijakan sekolah, kepemimpinan dan manajemen, kapasitas dan kultur, aktivitas peserta didik, kolaborasi dengan masyarakat luas, serta kurikulum dan pengajaran.

Konselor berupaya memberikan bimbingan dengan karakteristik khusus lainnya, yaitu dengan metode-metode psikologis dalam upaya mengembangkan kualitas kepribadian yang tang- guh, mengembangkan kualitas kesehatan mental, mengembangkan perilaku-perilaku yang lebih efektif pada diri individu dan lingkungannya, menanggulangi problema hidup dan kehidupan secara mandiri.

Hasil penelitian ini menguatkan hasil penelitian yang telah dilakukan oleh Jati (2014:34) bahwa menunjukkan bahwa prinsip "rumah bersama" memperlakukan siswa sebagai anggota keluarga dekat dalam pergaulan dengan sivitas akademika lainnya. Prinsip melting pot, tempat semua perbedaan ras, suku, agama, dan lainnya dilebur menjadi satu identitas tunggal sebagai saudara. Penerapan nilai universalitas mengenai tenggang rasa, toleransi, maupun perdamaian untuk menjaga semangat multikulturalisme dan memperkuat persaudaraan di antara para siswa.

Konseling juga telah menggunakan teknologi yang canggih. Seorang konselor dapat menggunakan operasi teknologi informasi manakala menghendaki, layanan yang diberikan lebih berkualitas. Menurutnya, ada beberapa standar etika yang harus ditaati, yaitu: merumuskan paham etika, membentuk prosedur melalui peraturan-peraturan yang ada, menetapkan sanksi, mengakui adanya perilaku etis, memfokuskan pada program pelatihan, melaksanakan tanggung jawab yang dibebankan, mendorong program rehabilitasi etika, mendorong partisipasi masyarakat profesional untuk membuat kode etik, menetapkan budaya keteladanan.

\section{SIMPULAN}

Berdasarkan hasil penelitian dapat disimpulkan bahwa secara umum proses pelaksanaan bimbingan konseling dengan pendekatan multikultur di SMA N 1 Palangkaraya yang dilaksanakan dapat berjalan dengan efektif. Secara rinci dapat disimpulkan: (1) tujuan layanan konseling multikultur adalah memberikan bantuan kepada siswa yang berlatar belakang multikultur untuk mengatasi masalah yang dihadapi dengan baik; (2) jenis-jenis layanan konseling yang diberikan kepada siswa multikultur antara lain membantu pribadi mengatasi masalah, merangsang klien mengembangkan perilaku santun, membantu mengatasi kecemasan atau konflik, dan lain-lain; (3) karakteristik khusus layanan konseling yang diterapkan yaitu dengan memerikan layanan konseling individual dengan memperhatikan secara seksama perbedaan etnis, agama, dan budaya tiap-tiap siswa; (4) layanan konseling multikultur 
telah memanfaatkan secara maksimal berbagai media konseling yang ada.

\section{UCAPAN TERIMA KASIH}

Terima kasih yang setulus-tulusnya penulis sampaikan kepada: 1) Ibu Dra. Badahsari, M.Pd., kepala SMA Negeri 1 Palangkaraya yang telah berkenan menerima dan mengijinkan kepada saya untuk meneliti BK multikultur, 2) guru BK Bapak Drs. Badri Lambang, Bapak Ahmadi, S.Pd, Ibu Ati Kuliahni, S.Pd, yang telah menyediakan seluruh data yang saya butuhkan, 3) seluruh guru, komite sekolah, pengurus OSIS, dan siswa yang telah berkenan menjadi informan penelitian.

\section{DAFTAR PUSTAKA}

Atamimi, Nuryati. 2015. "Keterampilan Psikologis Model Bimbingan Konseling Proaktif untuk Guru Sekolah Dasar." Jurnal Cakrawala Pendidikan, No 3, Oktober 2015. Online: http:www. http://journal. uny.ac.id/index.php/ cp/article/view/1480 (diunduh 1 Maret 2016).

Busro, M. 2015, "Bimbingan dan Konseling di Sekolah". Makalah tidak dipublikasikan. Serang: Universitas serang Raya.

Hohenshill, Thomas, H. 2013. "High Tech Counseling." Journal of Counseling and Development. V 78: 365-368.
Huberman, A., Michael dan Matthew B. Miles. 2000. "Data Management and Analysis Methods", dalam Norman K. Denzin dan Yvonna S. Lincoln (eds.), Handbooks of Qualitative Research. London: Sage Publications.

Jati, Wasisto Raharjo. 2014. "Toleransi Beragama Dalam Pendidikan Multikulturalismesiswa Sma Katolik Sang Timur Yogyakarta." Jurnal Cakrawala Pendidikan, No. 1, Februari 2014. Online: http:www. http://journal. uny.ac.id/index.php/ cp/article/view/1480 (diunduh 1 Maret 2016).

Saliman, Taat Wulandari, Mukminan Mukminan. 2014. "Model Pendidikan Multikultural Di 'Sekolah Pembauran' Medan.” Jurnal Cakrawala Pendidikan, No 3, Oktober 2014. online: http:www. http://journal. uny.ac.id/index.php/ cp/article/view/1480 (diunduh 1 Maret 2016).

Siskandar. 2013. Bimbingan dan Konseling di Sekolah, Jakarta: Pascasarjana Uhamka.

Sukardi, D.K.. 2014. Pengantar Pelaksanaan Program Bimbingan dan Konseling di Sekolah, Jakarta: Rineka Cipta.

Supangat. 2014. Bimbingan dan Konseling Lintas Budaya, Jakarta: Quantum Teaching.। 


\title{
PENINGKATAN PRESTASI BELAJAR MATEMATIKA \\ SISWA SMK MELALUI MODEL QUANTUM TEACHING \\ MELIBATKAN MULTIPLE INTELLIGENCE
}

\author{
Sofia Edriati, Hamdunah, dan Riri Astuti \\ Program Studi Pendidikan Matematika STKIP PGRI Sumatera Barat \\ email: sofia.edriati@yahoo.co.id
}

\begin{abstract}
Abstrak: Penelitian ini bertujuan untuk mengetahui peningkatan prestasi belajar matematika dalam pembelajaran yang menggunakan model quantum teaching yang diterapkan berdasarkan multiple intelligences yang dimiliki siswa. Penelitian ini merupakan penelitian eksperimen dengan rancangan Pretest and Posttest Group. Populasi penelitian adalah siswa kelas XI Jurusan Jasa Boga salah satu SMK di Kota Padang. Sampel sebanyak satu kelas dipilih secara cluster random sampling. Data diperoleh melalui angket multiple intelligence dan teknik pretes-postes. Data angket dianalisis secara kualitatif dan data pretes-postes dianalisis menggunakan skor gain ternormalisasi. Hasil penelitian menunjukkan bahwa terjadi peningkatan prestasi belajar matematika setelah mengikuti proses pembelajaran menggunakan model quantum teaching yang melibatkan multiple intelligence siswa.
\end{abstract}

Kata Kunci: Quantum Teaching, Multiple Intelligence, prestasi belajar

\section{THE IMPROVEMENT OF SMK STUDENTS' ACHIEVEMENT \\ IN MATHEMATICS THROUGH THE IMPLEMENTATION OF QUANTUM TEACHING MODEL FOCUSING ON MULTIPLE INTELLIGENCE}

\begin{abstract}
The objective of this study is to improvestudents' achievement in mathematics using quantum teaching model based on students' multiple intelligence. This study was an experimental study designed with pre-test and Post-test Group. The study population was class XI students of Department of Tata Boga at one of vocational schools in Padang which were selected through cluster random sampling. Data were obtained throughmultiple intelilligenceand pretest-posttest techniques. Questionnaire data were analyzed qualitatively and the pretest-posttest data were analyzed using a normalized gain scores. The results show that students' achievement in mathematics is improving after the learning process.
\end{abstract}

Keywords: Quantum Teaching, multiple intelligence, learning achievement

\section{PENDAHULUAN}

Tujuan pendidikan matematika pada jenjang pendidikan sekolah menengah adalah untuk memfokuskan pada penataan nalar dan pembentukan sikap siswa agar dapat menerapkan matematika dalam kehidupan. Tujuan pembelajaran matematika dapat tercapai apabila kegiatan pembelajaran matematika di sekolah berlangsung dengan baik. Dengan kata lain, metode mengajar perlu disesuaikan dengan gaya belajar siswa berdasarkan tipe kecerdasaan yang dimilikinya sehingga potensi siswa dapat digali dan dikembangkan.

Violinda (2012:3) menyatakan bahwa berdasarkan teori pembelajaran secara holistik bahwa proses pembelajaran yang berkualitas dapat terlaksana jika guru memiliki kemampuan untuk memahami karakteristik kecerdasan yang dimiliki oleh anak, dimana antara satu anak dengan anak lainnya berbeda karena setiap individu memiliki multiple intelligence. Dengan memahami kecerdasan yang dimiliki siswa, guru dapat mengakomodasi setiap siswa dengan berbagai macam pola pikirnya yang unik. Oleh karena itu, pembelajaran perlu melayani siswa secara individual untuk menghasilkan perkembangan yang sempurna pada setiap siswa.

Setiap orang mempunyai gaya belajar sendiri-sendiri dan tidak dapat dipaksakan untuk menggunakan gaya yang seragam. Di dalam kelas, beberapa siswa lebih suka terhadap guru yang mengajar dengan cara menuliskan segalanya di papan tulis, sehingga siswa bisa membaca dan memahaminya. Akan tetapi, beberapa siswa 
lain lebih suka guru yang mengajar dengan cara menyampaikannya secara lisan dan siswa mendengarkan agar bisa memahaminya. Sementara itu, ada siswa yang lebih suka membentuk kelompok kecil untuk mendiskusikan materi pelajaran. Nurani (2012:69) mengemukakan bahwa setiap anak harus mendapat perlakuan yang berbeda sesuai dengan potensi kecerdasannya masingmasing karena setiap individu memiliki cara yang berbeda untuk mengembangkan berbagai kecerdasan yang ada dalam dirinya.

Fleetham (Yaumi, 2012: 12) mengemukakan bahwa Multiple Intelligence atau kecerdasan jamak adalah berbagai keterampilan dan bakat yang dimiliki siswa untuk menyelesaikan berbagai persoalan dalam pembelajaran. Multiple Intelligence atau kecerdasan majemuk. Gardner mengemukakan bahwa kecerdasan jamak terdiri atas delapan tipe kecerdasan seperti disajikan pada Tabel 1.

Siswa dengan latar belakang kecerdasan yang berbeda-beda memiliki cara belajar yang berbeda-beda pula. Apabila guru mengajar tanpa memperhatikan multiple intelligence siswa, akan ada siswa yang kurang aktif dalam mengikuti proses pembelajaran, tidak terlibat dalam diskusi kelompok, atau tidak memperhatikan saat guru menerangkan. Akibatnya, banyak siswa yang mengalami kebingungan dalam menerima pelajaran matematika karena tidak mampu mencerna materi yang diberikan oleh guru. Pembelajaran matematika menjadi kurang menarik dan kurang menyenangkan bagi siswa. Oleh karena itu, guru perlu menerapkan model pembelajaran serta cara mengajar yang sesuai dengan gaya belajar siswa sehingga motivasi dan hasil belajar siswa dapat ditingkatkan.

Salah satu model pembelajaran yang membuka ruang bagi guru untuk dapat menerapkan berbagai cara mengajar yang mengakomodasi berbagai bentuk kecerdasan siswa adalah model Quantum Teaching. DePorter (2014:32) mengemukakan bahwa Quantum Teaching adalah penggubahan belajar yang meriah, dengan segala nuansanya, menyertakan segala kaitan, interaksi dan perbedaan yang memaksimalkan momen belajar. Guru dapat mempelajari keinginan dan harapan siswa sebagai dasar untuk memaksimalkan potensi yang mereka miliki melalui penggunaan model ini.

Kerangka rancangan belajar Quantum Teaching menurut DePorter (2014: 128) dikenal sebagai TANDUR, yaitu Tumbuhkan, Alami, Namai, Demonstrasi, Ulangi, dan Rayakan. Pada tahap Tumbuhkan, sertakan siswa dalam proses pembelajaran dengan memberitahu mereka manfaat yang bisa diperoleh (Apa Manfaatnya Bagiku?). Guru memberikan pengalaman baru kepada siswa pada Tahap Alami dengan memanfaatkan keinginan alami otak untuk mempelajari materi baru. Pada tahap Namai, guru membim-bing siswa untuk menemukan definisi, kata kunci ataupun konsep, memberikan identitas, serta mengurutkan. Penanaman konsep, mengajarkan keterampilan berpikir dan strategi belajar dibangun di atas pengetahuan dan keingintahuan siswa saat itu. Demonstrasi merupakan tahap dimana guru memberikan waktu dan kesempatan kepada siswa untuk menerjemahkan dan menerapkan pengetahuan siswa tentang materi yang baru saja

\section{Tabel 1. Delapan Tipe Kecerdasan Menurut Gardner}

\begin{tabular}{ll}
\hline \multicolumn{1}{c}{ Intelligences } & \multicolumn{1}{c}{ Description } \\
\hline Linguistic & $\begin{array}{l}\text { An ability to analyze information and create products involving oral and written } \\
\text { language such as speeches, books, and memos } \\
\text { An ability to develop equations and proofs, make calculations, and solve abstract } \\
\text { pogical- }\end{array}$ \\
$\begin{array}{l}\text { Mathematical } \\
\text { Spatial }\end{array}$ & $\begin{array}{l}\text { An ability to recognize and manipulate large-scale and fine grained spatial images } \\
\text { An ability to produce, remember, and make meaning of different patterns of sound }\end{array}$ \\
Musical & $\begin{array}{l}\text { An ability to identify and distinguish among different types of plants, animals, and } \\
\text { Neather formations that are found in the natural word }\end{array}$ \\
Bodily- & $\begin{array}{l}\text { An ability to use one's own body to create products or solve problems } \\
\text { kinesthetic }\end{array}$ \\
Interpersonal & $\begin{array}{l}\text { An ability to recognize and understand other people's moods, desires, motivations, } \\
\text { and intentions }\end{array}$ \\
Intrapersonal & $\begin{array}{l}\text { An ability to recognize and understand his or her own moods, desires, motivations, } \\
\text { and intentions }\end{array}$ \\
\hline Sumber: Davis, dkk (2012:6)
\end{tabular}


dipelajari ke dalam pembelajaran yang lain dalam kehidupannya. Tahap Ulangi dilakukan untuk mengetahui sejauh mana pemahaman siswa terhadap materi yang sudah dipelajari. Rayakan keberhasilan siswa dengan memberikan penghargaan untuk memberi rasa puas dengan menghormati usaha, ketekunan dan kesuksesan siswa.

Penelitian yang dilakukan oleh Martini, Rasna, dan Artawan (2014) menemukan kendala dalam penerapan metode quantum teaching adalah siswa yang memiliki kecerdasan dengan potensi yang berbeda-beda antara satu dengan yang lainnya. Pembelajaran yang dilakukan seharusnya memperhatikan perbedaan kecerdasan (multiple intelligence) tersebut. Sebagaimana diungkapkan oleh Tirtawati, Adnyana, dan Widiyanti (2014) bahwa metode pembelajaran kuantum menggunakan metodologi berdasarkan teori pendidikan, salah satunya adalah teori Multiple Intelligence.

Guru dapat merancang setiap bentuk interaksi, metode, dan strategi dalam penerapan quantum teaching yang sesuai dengan tipe kecerdasan yang dimiliki siswa sehingga guru dapat memasuki dunia siswa dan berdampak pada terbentuknya keunggulan.Huda dan Arief (2013:36) juga menyatakan bahwa pembelajaran yang melibatkan multiple intelligence berhubungan positif dengan prestasi belajar siswa pada aspek kognitif, afektif, dan psikomotor. Akan tetapi, hasil penelitian yang dilakukan oleh Rachmawati (2012:477) menunjukkan bahwa penerapan quantum teaching belum optimal dalam meningkatkan hard skill siswa tetapi sudah optimal dalam meningkatkan soft skill. Jadi, penerapan quantum teaching seharusnya memperhatikan multiple intelligence siswa sehingga proses pembelajaran yang dilakukan juga dapat meningkatkan hard skill. Oleh karena itu, penelitian penerapan quantum teaching melibatkan multiple intelligences dalam pembelajaran matematika ini dilakukan dengan tujuan untuk mengetahui apakah terjadi peningkatan prestasi belajar matematika siswa kelas XI SMK.

\section{METODE}

Penelitian ini merupakan penelitian eksperimen dengan rancangan Pre-test and Post-test Group. Populasi pada penelitian ini adalah siswa kelas XI Jurusan Jasa Boga salah satu SMK di Kota Padang. Penelitian membutuhkan sampel sebanyak satu kelas yang diambil secara acak dengan memperhatikan kesamaan rata-rata populasi. Hasil pengujian secara statistik menunjukkan bahwa populasi memenuhi asumsi kesamaan rata-rata sehingga pengambilan sampel dapat dilakukan secara cluster random sampling.

Instrumen yang digunakan dalam penelitian ini adalah angket Multiple Intelligences Research (MIR) dan soal pretes dan postes. Angket MIR bertujuan untuk mengetahui kecerdasan yang dominan dimiliki siswa, soal pretes dan postes berfungsi untuk mengukur peningkatan prestasi belajar matematika siswa.

Angket diberikan kepada siswa sebelum dilakukan proses pembelajaran menggunakan model Quantum Teaching. Angket MIR mencakup delapan kecerdasan yang dikemukakan Gardner. Setiap kecerdasan diwakili dengan 10 pernyataan. Angket MIR terdiri dari 80 pertanyaan yang harus dijawab oleh siswa dengan waktu yang sudah ditentukan selama 20 menit. Tes uji angket MIR dijawab oleh siswa secara individu, agar bisa diketahui kecerdasan masing-masing siswa dan tidak terpengaruh oleh temannya. Untuk mengetahui kecerdasan yang dominan dimiliki siswa, dilakukan perhitungan dengan cara menjumlahkan masing-masing skor siswa dari setiap kecerdasan, kemudian dilihat tiga skor yang tertinggi.

Data prestasi belajar siswa diperoleh berdasarkan hasil pretes dan postes yang dilakukan sebelum dan sesudah penerapan model pembelajaran Quantum Teaching. Analisis peningkatan hasil belajar siswa menggunakan rumus Gain Score dinormalisasi (Normalized Gain Score). Peningkatan hasil belajar dikategorikan tinggi apabila $g \geq 0,7$; termasuk kategori sedang apabila $0,3 \leq g<0,7$; dan kategori rendah apabila $g$ $<0,3$.

\section{HASIL DAN PEMBAHASAN}

Pengisian angket Multiple Intelligences Research (MIR) dilakukan oleh 20 orang siswa kelas sampel. Hasil perhitungan skor masingmasing siswa disajikan pada Tabel 2 .

Data pada Tabel 2 memperlihatkan tiga sampai empat kecerdasan dominan yang dimiliki siswa. Kecerdasan paling dominan di kelas sampel adalah kecerdasan interpersonal. Terdapat $82 \%$ siswa yang dominan pada kecerdasan tersebut. Ada satu siswa yang tidak memiliki kecerdasan interpersonal tetapi memiliki kecerdasan naturalis bersama 12 siswa lainnya. Di kelas sampel juga terdapat hanya satu siswa yang memiliki kecerdasan dominan spasial. Oleh karena itu, dalam 
penelitian ini digunakan strategi atau metode yang dapat mengakomodasi kecerdasan matematislogis, interpersonal, naturalis, dan spasial.

Tabel 2: Skor Kecerdasan Jamak Siswa

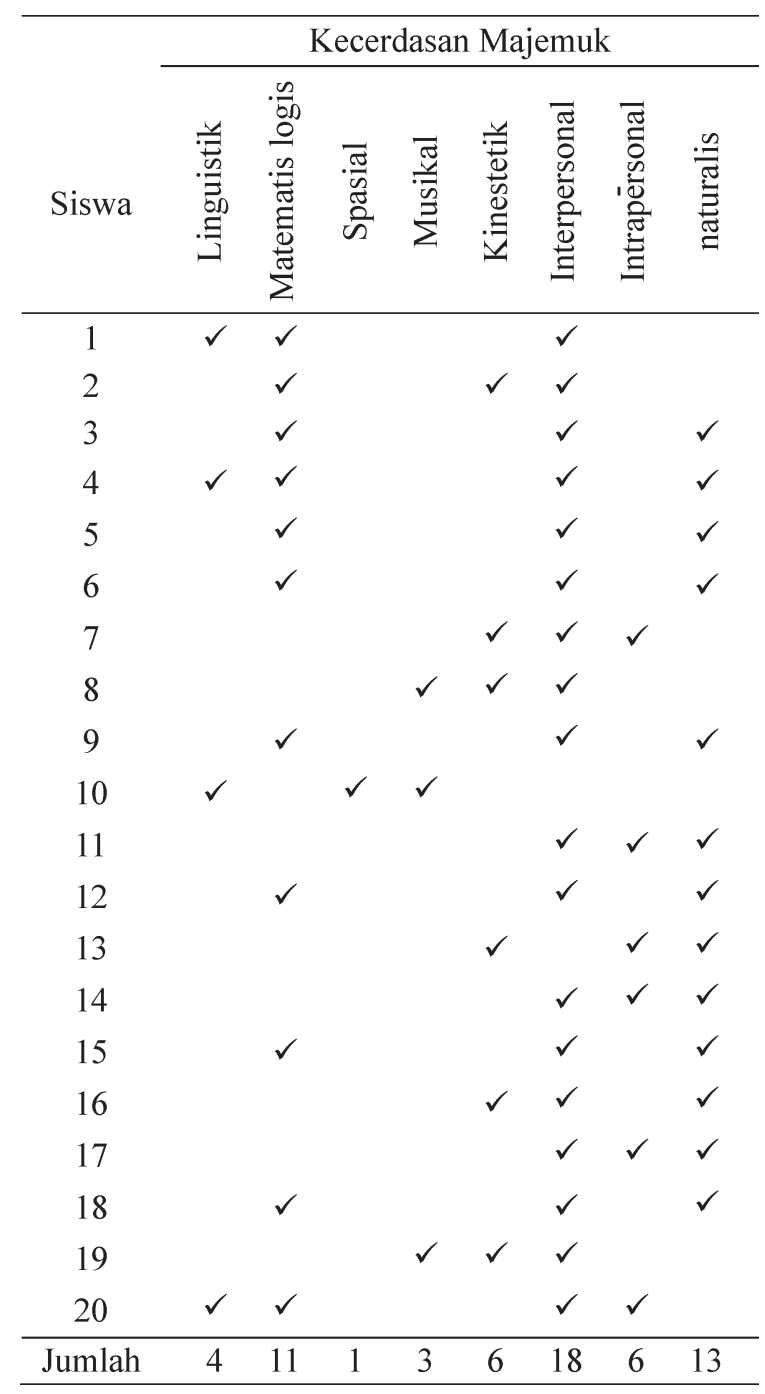

Sumber: Ronis (2000:51)

Pemilihan strategi atau metode pembelajaran yang dapat memfasilitasi keempat tipe kecerdasan tersebut dirancang dengan cara mempelajari prilaku yang relevan serta kegiatan belajar dan bentuk bahan ajar yang dibutuhkan. Kreativitas guru sangat diperlukan dalam menciptakan aktivitas belajar bermakna sehingga dapat menumbuhkembangkan kecerdasan majemuk peserta didik (2007). Strategi atau metode yang sesuai untuk empat tipe kecerdasan tersebut dijelaskan pada Tabel 3.

Model pembelajaran Quantum Teaching diterapkan dengan menggunakan strategi dan metode yang sesuai dengan perilaku yang relevan, kegiatan mengajar, dan bahan ajar yang dibutuh- kan. Pada tahap Tumbuhkan, guru memotivasi siswa dengan menyampaikan kompetensi yang akan dicapai siswa. Guru membuka pelajaran dengan menceritakan suatu masalah dan mengajukan pertanyaan mengarah pada materi yang berhubungan dengan alam sekitar dalam dunia siswa. Siswa dibawa keluar ruangan kelas untuk mempraktekkan soal cerita pada masalah yang diberikan. Guru meminta beberapa siswa dengan beberapa teman lainnya untuk memainkan peran pada masalah yang diberikan tersebut di luar ruang kelas sehingga dari penyelesaian permasalahan tersebut siswa mengetahui AMBAK (Apa Manfaatnya BAgiKu) dari materi yang sedang dipelajari.

Pada tahap Alami, guru memberikan suatu permasalahan yang ada dalam kehidupan nyata siswa, siswa terlibat langsung dalam penyelesaian permasalahan yang diberikan dan berinteraksi dengan teman untuk mengamati masalah serta mengaitkannya dengan pengetahuan yang sudah mereka miliki sebelumnya. Guru mendorong siswa untuk bertanya tentang materi. Siswa dibentuk dalam kelompok kerja yang beranggotakan 4 sampai 5 siswa dalam satu kelompok. Pada tahap Namai, kelompok diminta untuk mengumpulkan informasi, mengkaji tentang masalah terkait materi, melaksanakan penyelidikan masalah serta siswa dibimbing dalam kegiatan kelompok untuk membahas masalah dengan cara mengolah informasi (mengasosiasi) yang mereka dapatkan pada tahap sebelumnya. Pada tahap Demonstrasikan, siswa mengembangkan hasil diskusi kemudian mempresentasikantemuannya.

Pada tahap Ulangi, guru bersama siswa melakukan refleksi terhadap kegiatan pembelajaran yang sudah dilaksanakan untuk mengetahui sejauh mana pemahaman siswa terhadap materi yang dipelajari. Guru meminta siswa untuk membuat kesimpulan dari apa yang telah dipelajari dan menuliskan pada lembar yang disediakan dan mencentang lembar "Aku tahu bahwa aku memang tahu".Guru memberikan penghargaan, yaitu berupa penguatan verbal dan non verbal untuk menghormati usaha, ketekunan dan kesuksesan siswa. Penguatan verbal berupa pujian, pengakuan dan dorongan. Penguatan non verbal berupa hadiah alat tulis sepeti penggaris, pensil, pena dan penghapus.

Data hasil pretes dan postes matematika siswa pada kelas sampel dapat dilihat pada Tabel 4. Dari hasil pengujian normalitas data nilai 
pretes dan postes menggunakan uji KolmogorovSmirnov (KS) diperoleh nilai KShitung $_{\text {pretes }}=0,15$ dan KStabel $_{\text {pretes }}=0,28$, serta KShitung $_{\text {postes }}=0,10$ dan $K$ Stabel $l_{\text {postes }}=0,3$. Data ini menunjukkan bahwa KShitung $<$ KStabel, yang berarti bahwa data hasil tes siswa berdistribusi normal. Dengan demikian, teknik gain score dapat digunakan untuk menganalisis data hasil pretes dan postes.

Tabel 4. Rata-rata dan Gain Score Nilai Pretes dan Postes

\begin{tabular}{cccccc}
\hline Tes & $x_{\text {maks }}$ & $x_{\min }$ & $\bar{x}$ & $S$ & $\begin{array}{c}\text { Gain } \\
\text { score }\end{array}$ \\
\hline Pretes & 90 & 4 & 51,00 & 23,43 & 0,51 \\
Postes & 96 & 36 & 75,80 & 16,04 & (sedang) \\
\hline
\end{tabular}

Rata-rata nilai pretes dan postes matematika siswa kelas eksperimen mengalami peningkatan. Skor Gain yang dinormalisasi menunjukkan peningkatan prestasi belajar matematika dengan kategori sedang. Hal ini berarti bahwa prestasi belajar siswa mengalami peningkatan setelah diterapkan model pembelajaran Quantum Teaching yang melibatkan Multiple Intelligences.

Nilai pretes dan postes siswa dikelompokkan berdasarkan tipe kecerdasan dominan yang dimiliki. Pengelompokkan disusun berdasarkan tipe kecerdasan dominan yang difasilitasi dalam pembelajaran quantum teaching sehingga ada kelompok yang terfasilitasi pada dua dan tiga kecerdasan dominan serta ada juga yang hanya terfasilitasi pada satu kecerdasan dominan. Pengelompokkan nilai pretes dan postes berdasarkan tipe kecerdasan yang dominan dapat dilihat pada Tabel 5.

Grafik peningkatan nilai siswa berdasarkan tipe kecerdasan disajikan pada Gambar 1.

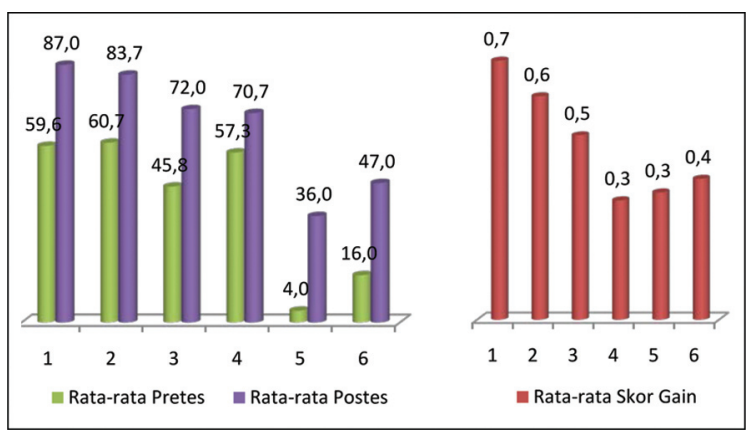

Gambar 1. Rata-rata Nilai Pretes, Postes, dan Skor Gain

Peningkatan nilai siswa pada setiap kelompok tipe kecerdasan yang dominan berada pada kategori sedang $(0,3 \leq g \leq 0,7)$. Peningkatan paling tinggi terdapat pada kelompok siswa yang memiliki tiga kecerdasan dominan dan peningkatan paling rendah diperoleh siswa memiliki satu tipe kecerdasan dominan yaitu siswa interpersonal dan siswa naturalis.

Metode yang digunakan guru untuk memfasilitasi siswa naturalis yaitu dengan membawa siswa ke luar ruangan cukup membuat siswa antusias. Akan tetapi, kegiatan yang dilakukan belum menghubungkan proses ataupun materi pelajaran dengan alam dan lingkungan sehingga siswa naturalis belum bisa memahami dengan baik materi pelajaran.

Kegiatan yang dilakukan guru dengan meminta beberapa siswa berdiri bersusun sehingga terbentuk susunan matriks sambil memegang media yang telah disediakan sangat memfasilitasi siswa matematis-logis dan siswa spasial. Media yang digunakan dapat dilihat pada Gambar 2.

\section{Tabel 5. Pengelompokkan Nilai Siswa Berdasarkan Tipe Kecerdasan Dominan}

\begin{tabular}{clcccc}
\hline Kelompok & Tipe Kecerdasan Dominan & $\begin{array}{c}\text { Jumlah } \\
\text { Siswa }\end{array}$ & $\begin{array}{c}\text { Nilai } \\
\text { Pretes }\end{array}$ & $\begin{array}{c}\text { Nilai } \\
\text { Postes }\end{array}$ & $\begin{array}{c}\text { Skor } \\
\text { Gain }\end{array}$ \\
\hline 1 & Matematis-logis, & 7 & 59,6 & 87,0 & 0,7 \\
& $\begin{array}{l}\text { Interpersonal, Naturalis } \\
2\end{array}$ & 3 & 60,7 & 83,7 & 0,6 \\
& $\begin{array}{l}\text { Matematis-logis, } \\
\text { Interpersonal }\end{array}$ & & & & \\
3 & Interpersonal, Naturalis & 5 & 45,8 & 72,0 & 0,5 \\
4 & Interpersonal & 3 & 57,3 & 70,7 & 0,3 \\
5 & Naturalis & 1 & 4,0 & 36,0 & 0,3 \\
6 & Spasial & 1 & 16,0 & 47,0 & 0,4 \\
\hline
\end{tabular}




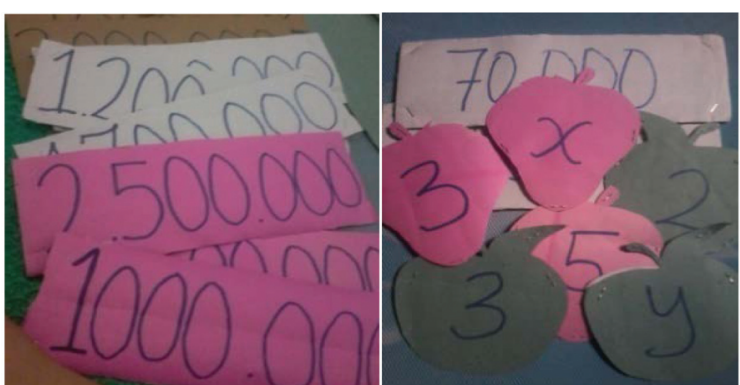

Gambar 2. Media Visual dalam Memperkenalkan Konsep Matriks

Siswa-siswa yang lain mengamati media yang dipegang temannya dan menentukan matriks-matriks yang terbentuk. Kegiatan ini sangat memfasilitasi satu-satunya siswa dengan tipe kecerdasan dominan spasial di kelas tersebut. Dilihat dari hasil tes, siswa tersebut termasuk kelompok yang memiliki prestasi belajar rendah pada mata pelajaran matematika. Akan tetapi, skor gain yang diperoleh siswa tersebut berada pada kategori sedang. Dengan kata lain, peningkatan yang terjadi cukup signifikan dan lebih tinggi daripada siswa naturalis dan siswa interpersonal-naturalis. Temuan ini didukung oleh Gardner (2011:10) yang menyatakan bahwa saat ini tidak dibutuhkan banyak orang yang memiliki kecerdasan tinggi atau kecerdasan ganda, yang dibutuhkan adalah individu yang dapat menggunakan kecerdasannya untuk tujuan-tujuan positif.

Kegiatan mengisi Lembar Tugas yang disediakan guru sangat memfasilitasi siswa matematis-logis. Contoh hasil kerja siswa dapat dilihat pada Gambar 3.

Kegiatan diskusi kelompok dan presentasi juga dilakukan untuk memfasilitasi siswa dengan kemampuan interpersonal yang merupakan kemampuan paling dominan di kelas sampel. Penggunaan masalah-masalah realistik seharusnya membantu siswa naturalis dalam memahami materi pelajaran, siswa interpersonal akan senang mengajarkan kepada temannya tentang apa yang dia ketahui, dan dibantu oleh siswa matematislogis untuk perhitungan yang lebih akurat.Akan tetapi, siswa belum bisa bekerja sama dan berinteraksi dengan baik. Kegiatan saling mengajar (tutor sebaya) yang dilakukan siswa belum berjalan dengan baik karena beberapa siswa sangat mendominasi kegiatan diskusi. Penelitian yang dilakukan oleh Aryani, Sudjito, dan Sudarmi (2015:6) juga menemukan siswa-siswa yang ingin mendominasi dalam pelaksanaan kegiatan kelompok yang diterapkan dalam pembelajaran yang telah dirancang sesuai dengan teori multiple intelligence.

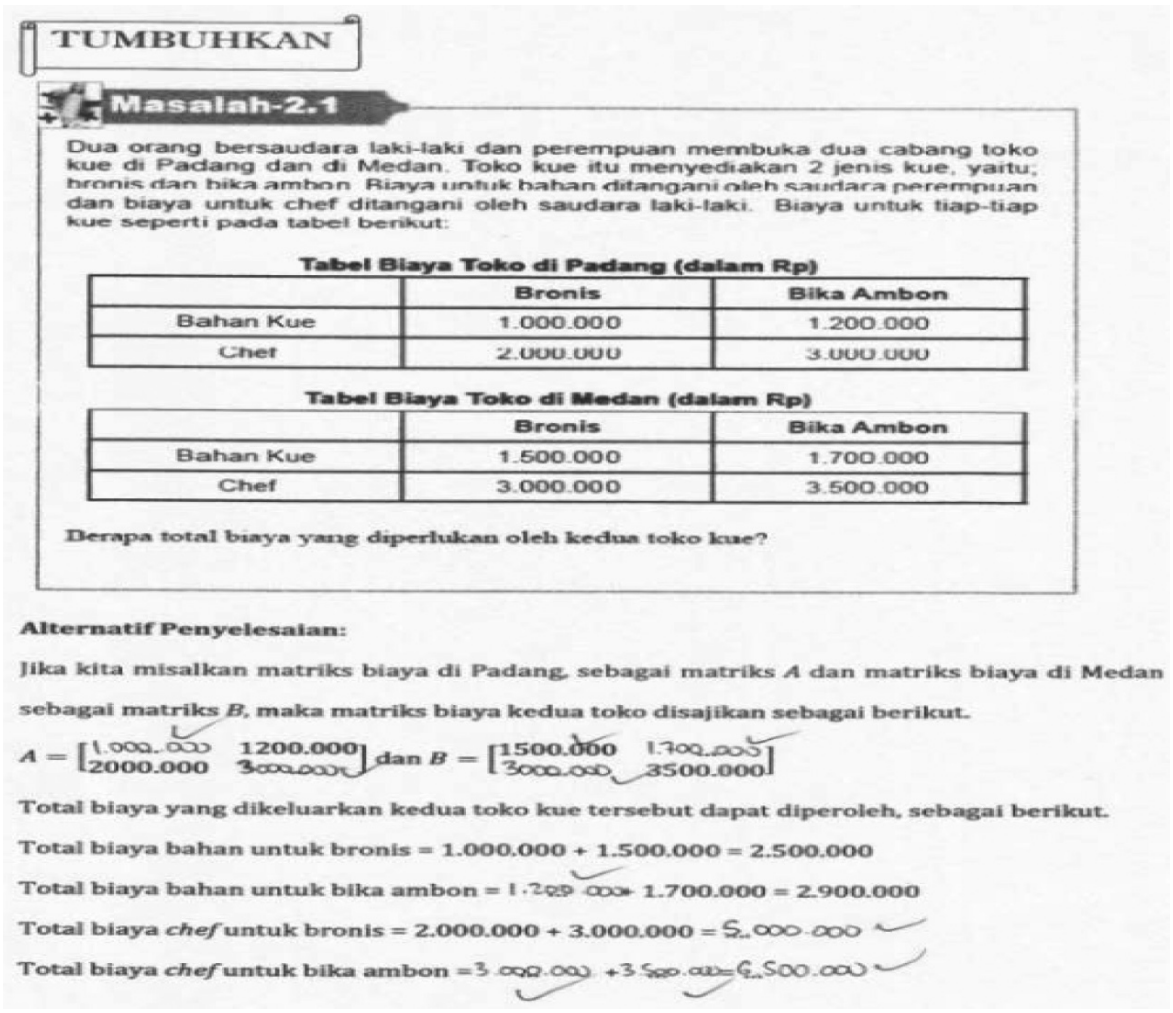

Gambar 3. Lembar Tugas Siswa 


\section{PENUTUP}

Berdasarkan hasil dan pembahasan, pembelajaran quantum teaching yang telah dilaksanakan telah berhasil meningkatkan prestasi belajar siswa. Peningkatan paling signifikan terjadi pada siswa yang memiliki kecerdasan dominan matematislogis, interpersonal, dan naturalis. Dengan demikian, disarankan beberapa hal, yaitu: (1) untuk memfasilitasi metode dan strategi pembelajaran di kelas berdasarkan tipe kecerdasan (multiple intelligences) yang dimiliki siswa agar prestasi belajar siswa mengalami peningkatan; (2) pembelajaran yang bersifat kontekstual dan realistik dapat memfasilitasi siswa dengan tipe kecerdasan naturalis apabila siswa berada langsung di alam atau lingkungan yang terkait dengan materi pelajaran, 3) kegiatan belajar tutor sebaya atau kerjasama kelompok yang memfasilitasi siswa interpersonal perlu memperhatikan prinsip-prinsip pembelajaran kooperatif.

\section{UCAPAN TERIMA KASIH}

Ucapan terima kasih ditujukan kepada: 1) Ibu Villia Anggraini, M.Pd., Ibu Alfi Yunita, M.Pd, dan Ibu Ainil Mardiyah, M.Si atas sumbang saran yang telah diberikan dalam pelaksanaan penelitian ini, 2) Mitra Bestari dan Tim Editing Cakrawala Pendidikan yang banyak memberikan masukan dalam penulisan artikel ini.

\section{DAFTAR PUSTAKA}

Aryani, Agustin Dwi, Sudjito, Debora Natalia, dan Sudarmi, Marmi. 2015. "Penerapan Model Pembelajaran Berdasarkan Teori Multiple Intelegence (MI) yang Dominan dalam Kelas Pada Materi Tekanan". Jurnal Radiasi,06 (1):1-10.

Davis, Katie, dkk. 2012. "The Theory of Multiple Intelligences". Online: https://howardgardner01.files.wordpress.com/2012/06/443davis-christodoulou-seider-mi-article.pdf

DePorter, Bobbi, Reardon, Mark \& SingerNourie, Sarah. 2014. Quantum Teaching. Bandung: PT Mizan Pustaka.

Gardner, Howard. 2011. "The Theory of Multiple Intelligences: As Psychology, as Education, As Social Science". Online: https://howardgardner01.files.wordpress. com/2012/06/473-madrid-oct-22-2011pdf.

Hake, Richard R. 1998. "Interactive-engagement Versus Traditional Methods: A Six-thousand-student Survey of Mechanics Test Data for Introductory Physics Courses". Jurnal Department of physics, Indiana University, Bloomington, No. 1.

Huda, Miftachul, dan Arief, Alimufi. 2013. "Pengaruh Multiple Intelligences Menggunakan Model Pembelajaran Kooperatif Tipe Jigsaw terhadap Hasil Belajar Siswa pada Pokok Bahasan Listrik Dinamis Kelas X Di SMAN 1 Porong". Jurnal Inovasi Pendidikan Fisika, 02 (03): 34 - 37.

Martini, Ni Made, Rasna, I Wayan, dan Artawan, I Gede. 2014.'Implementasi Model Pembelajaran Quantum Learning dalam Pembelajaran Menulis Karangan Deskripsi pada Siswa Kelas X SMKN 1 Abang". e-Journal Program Pascasarjana Universitas Pendidikan Ganesha Program Studi Pendidikan Bahasa dan Sastra Indonesia, vol. 3.

Nurani, Yuliani. 2012. "Pengembangan Media Daur Ulang Berbasis Kecerdasan Jamak dalam Peningkatan Keterampilan HidupAnak Usia Dini”. Cakrawala Pendidikan, XXXI (1), 67-81.

Rachmawati, Rima. 2012. "The Implementaton Quantum Teaching Methodof Graduate Through Up-Grade Hard Skill and Soft Skill(Case study on Management Accounting Class)". Procedia--Social and Behavioral Sciences, 57: 477 - 485.

Tirtawati, Ni Luh Ratna, Adnyana, Putu Budi, dan Widiyanti, Ni Luh Putu Manik.2014. "Pengaruh Pembelajaran Kuantum (Quantum Learning) dan Peta Pikiran (Mind Mapping) terhadap Keterampilan Berpikir Kreatif dan Hasil Belajar Biologi Siswa SMA. e-Journal Program Pascasarjana Universitas Pendidikan Ganesha Program Studi IPA,Vol. 4.

Violinda, Qristin. 2012. "Implementasi metode smart learning solution berdasar teori 
multiple inteligence dalam pengembangan potensi anak usia dini". Indonesian Journal of Early Childhood Education Studies, 1(1): 1-6
Yaumi, Muhammad. 2012. Pelajaran Berbasis Multiple Intelligences. Jakarta: PT Dian Rakyat. 